\title{
The House of the Dusper Family in the Kraljeva Sutjeska near Kakanj (Bosnia and Herzegovina)
}

\author{
Ahmet Hadrović ${ }^{*}$ \\ Faculty of Architecture, University of Sarajevo, Sarajevo, Bosnia and Hercegovina
}

Citation: Hadrovic A. The House of the Dusper Family in the Kraljeva Sutjeska Near Kakanj (Bosnia and Herzegovina) SEE $J$ Archit Des. 2020 Mar 11; 10046:1-5. http://dx.doi.org/10.3889/seejad.2020.10046

Key words: Dusper family; Monastery; Mosque; Complexity and controversy; Traditional architecture

'Correspondence: Prof Dr. Ahmet Hadrović, Faculty of Architecture, University of Sarajevo, Sarajevo, Bosnia a Hercegovina. E-mail: ahmeth@af.unsa.ba

Received: 06-Apr-2020; Revised: 20-Apr-2020; Accepted: 26-Apr-2020; Published: 11-Mar-2020

Copyright: ๑ 2020 Ahmet Hadrović. This is an open-access article distributed under the terms of the Creative Commons distribution and reproduction in any medium, provided the original author and source are credited.

Competing Interests: The author have declared that no competing interests exist.

\begin{abstract}
Bosnia and Herzegovina is in many ways a special, complex and controversial geographical, geopolitical and social space. As a state, it is home to "three constituent peoples“ and "other" citizens. As such, it had a tumultuous history, with magnificent examples of coexistence, humanity and respect for its peoples, cultures, and religions, as well as examples of expressing cruelty to one another.

Kraljeva Sutjeska is a relatively small town near Kakanj whose historical importance for the state of Bosnia and Herzegovina. Its location in central Bosnia, in the gentle plain that emerges from the rocky strait (.sutjeska“) of the Trstivnica river, was the ideal natural place for the development of the city (,suburb“) of the medieval rulers of Bosnia, that is, the royal residence (Banski dvor-Curia bani) of bans/kings from the Kotromanić house. In addition, Bobovac is located northeast ( $3.5 \mathrm{~km}$ by air), as a fortified royal city.

Franciscan monastery in Kraljeva Sutjeska with the church of st. John the Baptist (erected in the early 14th century) and the mosque of Sultan Mehmed II El Fatih (erected in 1463) are the two most significant public sites and cultural-historical monuments that, in architectural terms, follow the patterns of two great civilizations-Christianity and Islam.

The house of the croatian Dusper family in Kraljeva Sutjeska is a private residential building which, as such, is not the result of religious-cultural canons but an example of the genesis of architectural content, which at the same time, in its development, receives many different influences: building-architectural, religious, cultural, artistic ... The observer from the side (and especially by getting acquainted with the development of her spatial plan, interior decoration and individual elements of the equipment), depending on his culture, religious affiliation (...), will see a croatian-catholic house in the Dusper family house, and others-bosnian housechardaklia or oriental type town house in Bosnia and Herzegovina. For this reason, the Dusper family house in Kraljeva Sutjeska is an invaluable architectural and cultural content, both for bosnian croats and for Bosnia and Herzegovina (which best represents its cultural complexity) and for architecture and culture on a global scale.
\end{abstract}

\section{Introduction}

Kraljeva Sutjeska is located in the central part of Bosnia and Herzegovina, away from Sarajevo around (Figure 1). By the size of its physical structure and the variety of its architectural features, the settlement is located between the village and the town. In terms of its historical significance, Kraljeva Sutjeska occupies an extremely important place in the identity of Bosnia and Herzegovina since its three national monuments are located there: the Franciscan monastery with the church of St. Nicholas. John the Baptist (erected in the first half of the 14th century), Sultan Mehmed II El Fatih Mosque (1463) and the
Dusper family home (early 19th century). As today's Kraljeva Sutjeska developed on the site of the suburbs of the fortified town of bosnian kings (Bobovac) from the Kotromanić house, that is, at the site of their court-residence (Banski dvor-Curia bani), this fact remains, until today, the most important and immense "embodied energy" for generations of its inhabitants. This is confirmed, among other things, by the preserved custom that women of this place still wear black today on the day of the death of the last Bosnian queen, Katherine Kosaca (1425-1478), who left the fortified town of Bobovac and Bosnia and Herzegovina in front of the Ottoman forces led by Sultan Mehmed II El Fatih (1463). 
Near Kraljeva Sutjeska there are several caves carved into the rocks which are supposed to have been guard houses from which access to the former royal town of Bobovac was controlled. It is a well-preserved tradition among the people that these caves were used as an outpost for monks and dervishes [1].

While the monastery with the church of St. John the Baptist and Mosque of Sultan Mehmed II public buildings, representatives of the great Catholic order, that is, the Ottoman Empire, organized according to their canons, the same for a wide geographical and cultural space, is the house of the Dusper family, as a private object, an architectural content that reflects the human needs of the level of one family, the result of extremely dynamic influences, both of the natural and social environment, on the one hand, and of man (the wide array of features of his being), on the other, it is a representative example of the genesis of architecture and the specificity of Bosnia and Herzegovina as a multi-ethnic, multireligious and a multi-cultural society.

According to all the above, the house of the Dusper family in Kraljeva Sutjeska is a particularly representative example for the study of architecture in context, that is, the study of defining architectural space [2].

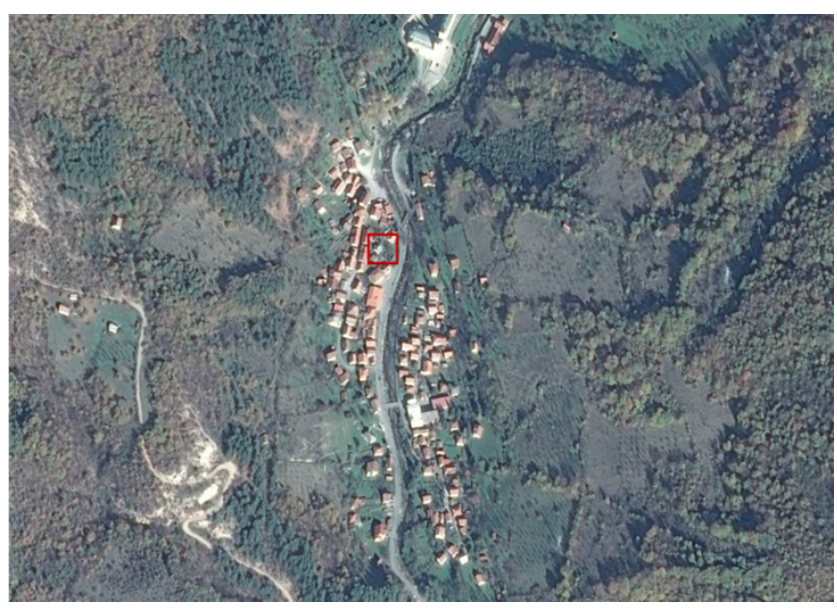

Figure 1: House of the Dusper family in Kraljeva Sutjeska. Location (geographical coordinates: $44^{\circ} 07^{\prime} 13.29^{\prime \prime} \mathrm{N}$; $18^{\circ} 12^{\prime} 03.79^{\prime \prime} \mathrm{E}$; Elevation: $492 \mathrm{~m}$ ). Source: Google Earth (Accessed: 2/10-2020)

\section{Spatial - Shape Characteristics of the House}

Considering the development of horizontal and vertical house plans, a variety of contents, construction and materialization, and general architectural and design appearance, the Dusper family house in Kraljeva Sutjeska is at the junction between the richest country houses, the Bosnian chardaklija house, and the oriental type city house. As a Bosnian house-chardaklija, this house has the characteristics of a three-way chardaklia type, on the level of the floor and attic, that is, a type of two-way chardaklia on the ground floor level, which makes it specific. With the development of the vertical plan, in the ground-floor-chardak scheme among the horns („čardakovi među rogovima"), this house in all respects corresponds to the classical type of the Bosnian chardaklija house [3]. In the original use of the house, the ground floor had the function of a barn, which is a unique case in the chardaklia house in central Bosnia, and almost a regular case in the chardaklija house in western Bosnia [3], [4]. On the ground floor level there are two upstairs approaches, one on the main front of the street-oriented house with a porch and the other in the back of the house, oriented to the garden and orchard (Figure 2).

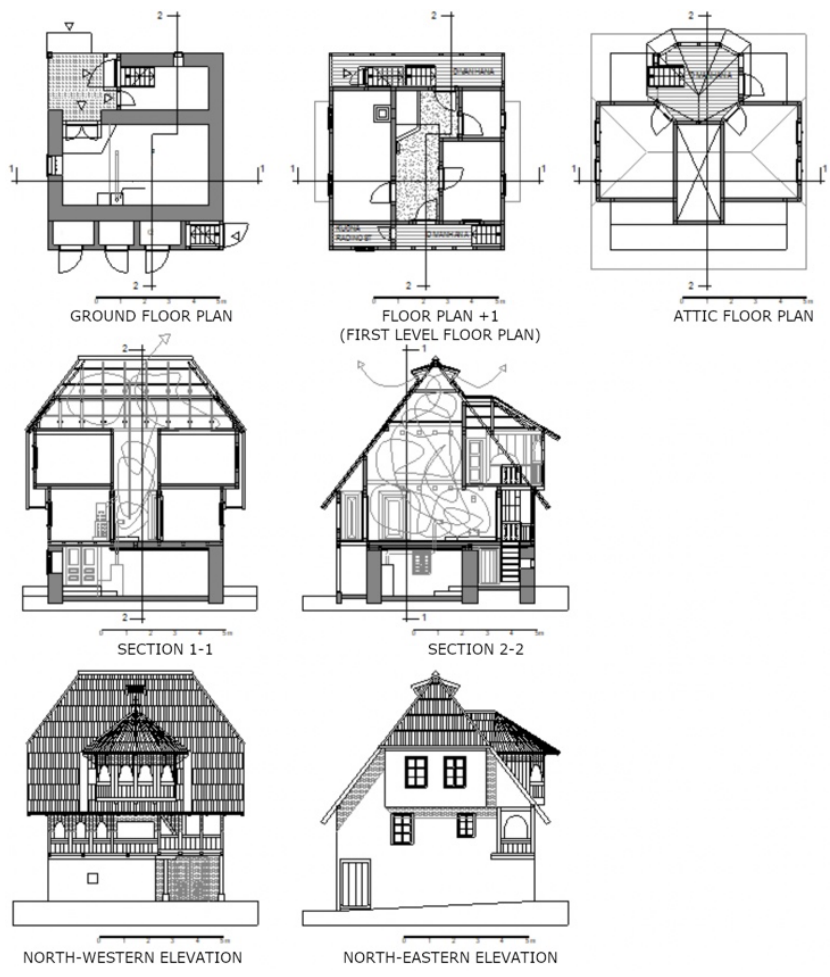

Figure 2: House of the Dusper family in Kraljeva Sutjeska (Drawings: Prof. Ahmet Hadrović, 2016)

The house of the Dusper family is unique among of the chardaklia-houses in Bosnia and Herzegovina, where, as a rule, access to the floors located on the sides of the house is treated equally in every respect, since the house is always a citizen in the way of its possible division into equal parts, symmetrical in the vertical plane. The approaches to the floor in the case of the Dusper family house reflect the specificity of the family (West Catholic culture), where the entrance facade is a "public family picture“ and the facade in its hinterland is a „private family picture" (Figure 3). 


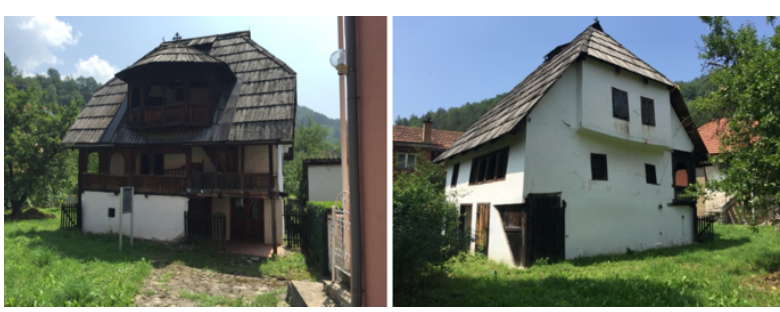

Figure 3: House of the Dusper family in Kraljeva Sutjeska

In this view, the Dusper family house follows the basic morphology pattern of the Oriental-type town house, which in its most developed form has a separated public zone (selamluk) and a private zone (haremluk). While in the Oriental type town houses, these zones are spatially developed [2], in the case of the Dusper family home the same spaces are used as public and private-family spaces, where a privatefamily entrance in the back of the house is a solution for performing those family activities that are „not visible to the public". This is best seen in the fact that in the part of the divanhana (covered terrace) in the back of the house is arranged a „business premises“tailoring workshop, which can be accessed from the outside without going through the main contents of the house (Figure 4).

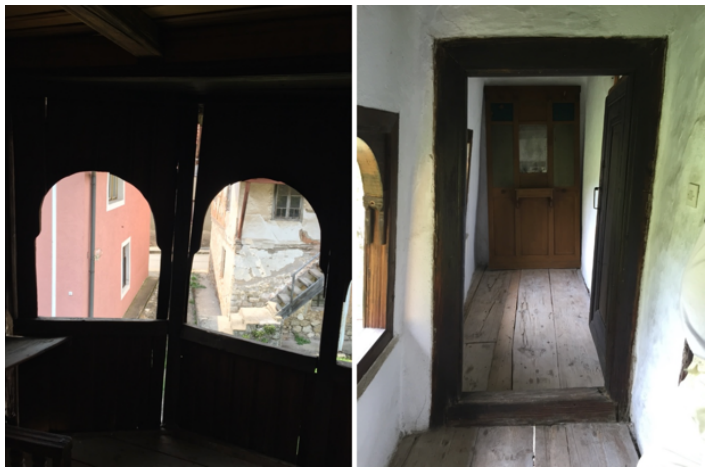

Figure 4: Vizure from the large divanhana towards the street access (left) and part of the garden-oriented divanhana arranged as a tailoring workshop (right)

At the level of the floor, which is arranged according to the typical scheme of a three-tract bosnian chardaklia house, in the central tract is the „house“ („kuća“), a space with a central open fireplace to the roof area (Figure 5), while in the other two tracts accessed from the space with open fireplace, two main rooms and one pantry (Figure 6, Figure 7, and Figure 8), next to the open fireplace. The brick kiln in the main room has a flue outlet into the fireplace area, still towards the attic (Figure 5).

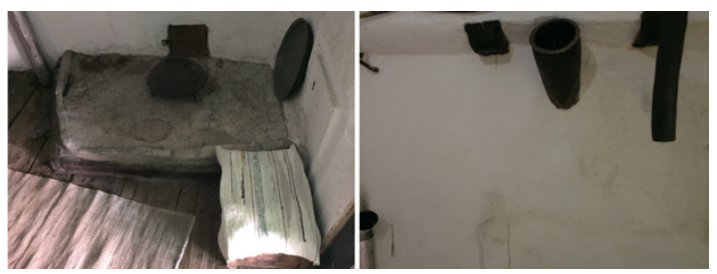

Figure 5: Open fireplace in the „home“ („kuća“) space

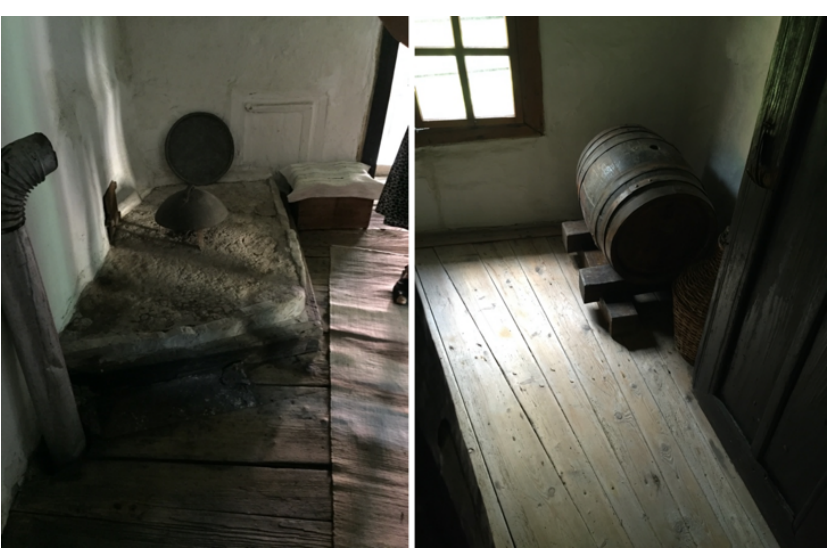

Figure 6: The area of the „house“ („kuća“) with a open fireplace (left) and a pantry next to the open fireplace
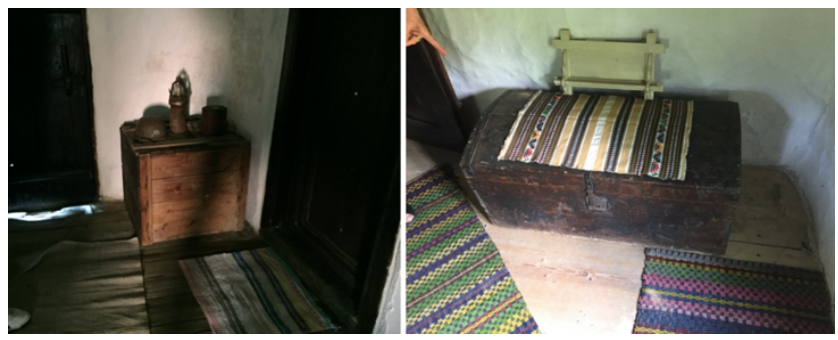

Figure 7: Wooden crate for storing household utensils in the "home" space (left) and the girly wooden storage box („sehara") in the upstairs room (right)
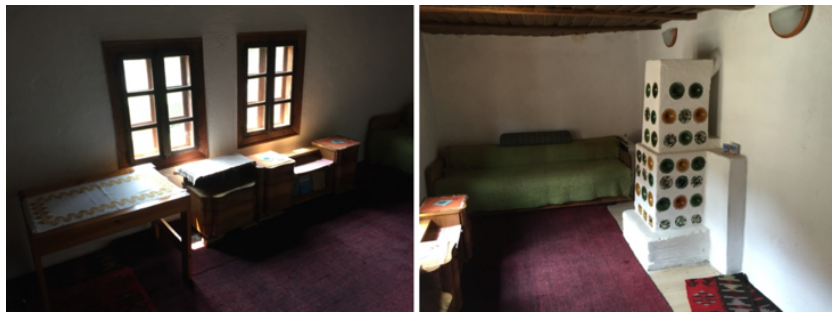

Figure 8: Arrangement of a large upstairs room

At the attic level, there are two "chardaks among the horns“ („čardak među rogovima“) and an open space („dimluk“) that connects the open fireplace to the attic (Figure 2, Figure 9, and Figure 10). On the side of the entrance facade is an extremely representative loggia from which it is accessed into chardaks. This loggia is a specific solution in Bosnia and Herzegovina, which corresponds to the "divanhana" of the Bosnian chardaklija house, or to the „kamerija“-the enlarged and especially emphasized part of the divanhana [2], (Figure 3).
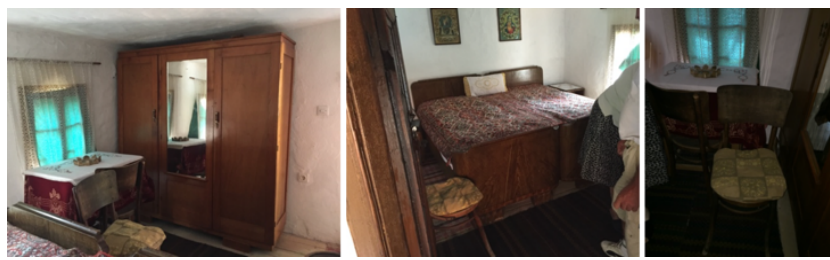

Figure 9: Arrangement of one of the chardaks 


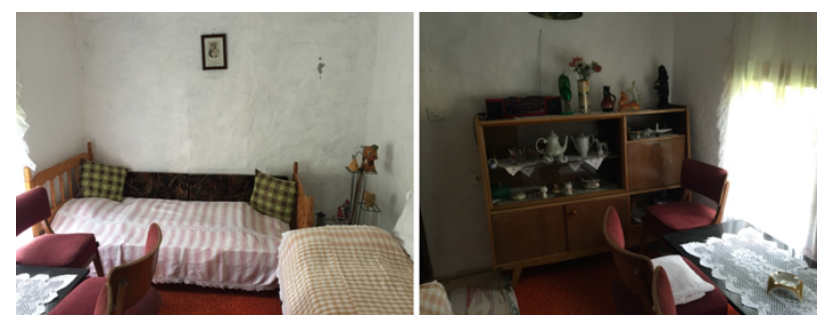

Figure 10: Arrangement of the second chardak

The roof of the Dusper family home is also unique. While the classical solutions of the bosnian chardaklija house and the oriental-type city house in Bosnia and Herzegovina are regularly quadruple, the Dusper family roof is two-story, with small cuts (,lastavice“) on its front sides, which corresponds to the formative details of an alpine house across Western Europe (Figure 2, Figure 11, left).
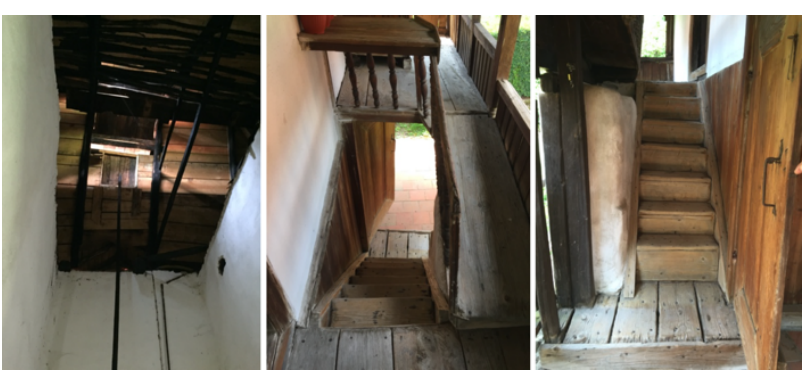

Figure 11: Open-space area („dimluk"), from the open fireplace to the attic (left) and staircase with divanhan on the entrance facade (right)

\section{Construction and Materialization}

With its construction and materialization, and its original use of space, the Dusper family house in Kraljeva Sutjeska follows the patterns of the classical Bosnian house of the chardaklija. Materials are natural, taken on site: stone, adobe-brick („ćerpič“) and wood. The plaster used to build the stone wall on the ground floor and the plastering of the interior and exterior surfaces, made of sand (taken from the banks of the Trstionica river) and lime produced in local roasting stone („kračane“).

The walls of the ground floor are made of stone, today plastered, while the walls of the ground floor and attic are built in bondruk-system with fill of adobe-brick. The roof structure and cover are made of wood („šindra“) whose durability is great since, in the original use of the house, they are permanently exposed to smoke, where smoke and tar protect the wood from insects and rot. The use of wood in the construction of the roof structure and cover is extremely appropriate not only for the natural environment, but also for the use of the space of the house where open fireplace is crucial.
The stairs („basamaci“) are made of beech wood, which over time has been given a special honey color (Figure 11).

The ceiling structures are made of wooden beams where sand is used as a sound insulation between the finely treated ceiling of wooden boards and the floors of thick wooden boards (Figure 12).

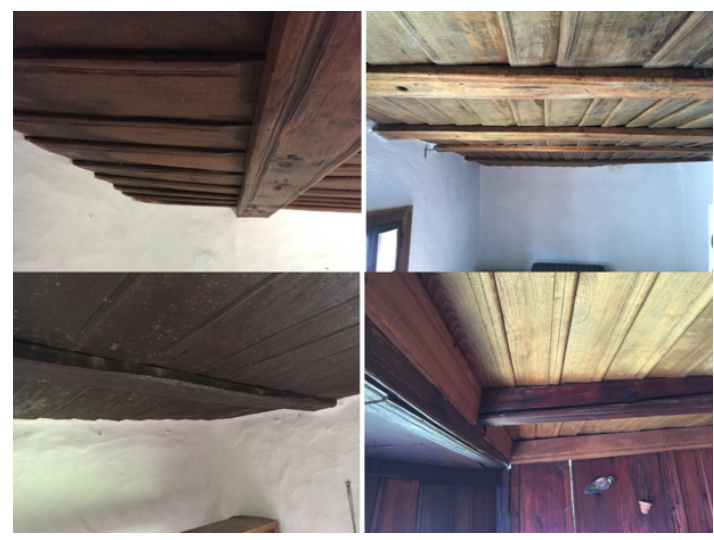

Figure 12: Wooden ceilings („šiše“) on the premises

The floor in the central floor level tract, where the open fireplace is located, is made of compacted earth with the addition of animal hair, as reinforcement. Wooden floors are covered in all bosnian rooms with traditional bosnian rugs and ribbons (Figure 13).
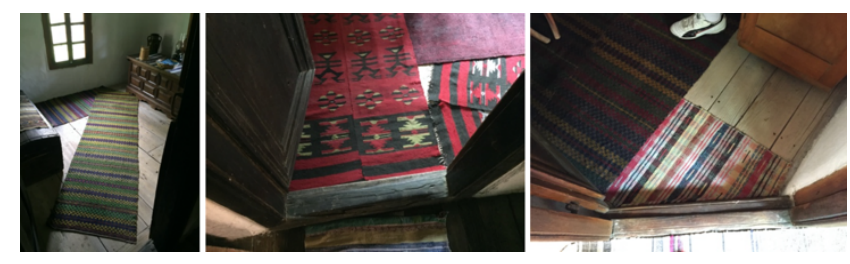

Figure 13: Arrangement of floor surfaces

\section{Doors and Windows}

The door on the Dusper house is a small rectangular gauge, with a different level of craftsmanship. Some doors are very simple (Figure 14), while others are exceptional crafts that obviously need to be representative of family status (Figure 15).
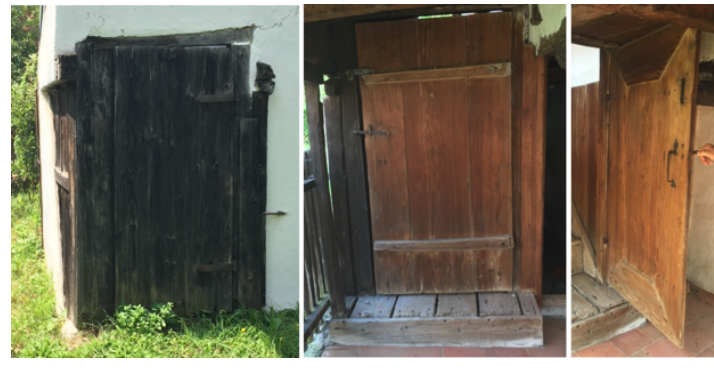

Figure 14: Doors on access stairways for first floor 


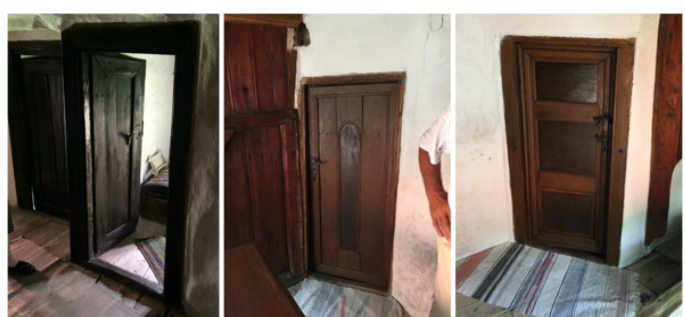

Figure 15: Doors in rooms next to the open fireplace (left) and doors in chardaks (center and right)

The color of the wood from which the doors and windows are made has a honey color that comes from the fact that the wood there was exposed to smoke from the open fireplace, in the original use of the home space. Here, smoke from an open fireplace, similar to a roof structure and cover, is the main means of protecting wood from insects and rot.

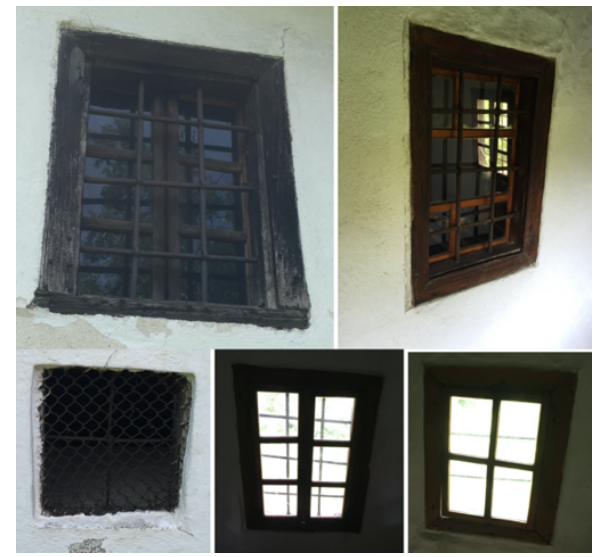

Figure 16: Different window design

The windows of the house are rectangular in size, design and materialization of which follow the patterns of the bosnian chardaklija house. The windows are single, usually double-glazed, the wings of which are divided into three windows with single glazing. The windows are set at the level of the outer surface of the wall, framed by wooden boards on the outside, while wooden benches on the inside. Some windows have mechanical protection-wrought iron demirrils, (Figure 16 and Figure 17).

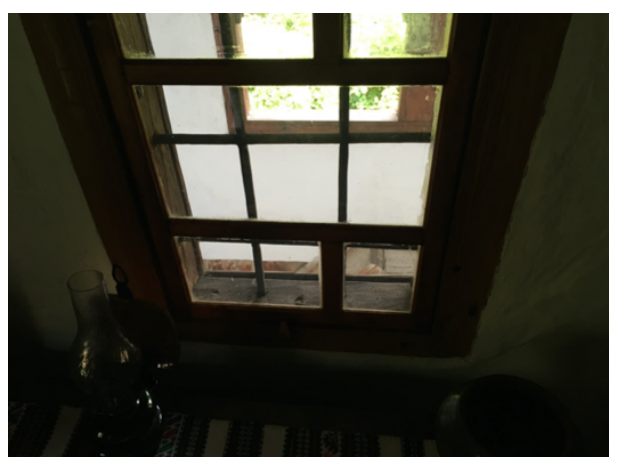

Figure 17: Window to „monitoring“ entrances from the girls' room (upstairs)

\section{Perspectives}

The Dusper family house in Kraljeva Sutjeska is, after all, a remarkable example of a traditional family house in Bosnia and Herzegovina, which, in its conception, form, construction and materialization, reflects the natural environment, the extremely complex social environment, and the family, that is, human. As such, it has universal world values that can set a good example for the study of major architectural themes (architecture in context, defining architectural space, for example). At the same time, it is the best example for the study of the complexity and conradiction of Bosnia and Herzegovina as a multi-ethnic, multi-religious and multi-cultural society. At the local level, it is one of the key testimonies of the history and culture of the Kraljeva Sutjeska.

At the time of making this work, the Dusper family house in Kraljeva Sutjeska is privately owned and can be visited with prior notice. As homeowners are in their late years, the big and delicate question is how the home will be used in the future. Although this house has the status of a national monument of Bosnia and Herzegovina, it is not a guarantee of its survival in the future, as evidenced by numerous examples throughout Bosnia and Herzegovina where national monuments are "dead", such as open-air museum specimens, in a state of permanent atmospheric exposure and other devastations, they are merely witnessing history. The Dusper family house has the prospect of being "alive“ provided it is given adequate social status. The best solution would be for it to continue to be a "home to live in". It could also have the function of a museum (local, regional or national level) with a clearly organized system of selfsustainability. A possible solution could be to have this house within the monastery in Kraljeva Sutjeska, as the annexe of its museum. Given the history of Bosnia and Herzegovina, the prospects for the future of this house may be directed in the best direction, but also in the opposite direction. This work was done with the aim that the house of the Dusper family in Kraljeva Sutjeska has perspectives directed in the best direction.

\section{References}

1. Hadrović A. Arhitektura uklesana u stijene. Sarajevo: Arhitektonski fakultet u Sarajevu; 2019.

2. Hadrović A. Defining Architecrural Space on the Model of the Oriental Style City House in Bosnia and Herzegovina, Serbia, Montenegro, Kosovo and Macedonia. North Charleston, SC, USA: Booksurge, LLC; 2007.

3. Hadrović A. Bosanska kuća čardaklija, Sarajevo. Sarajevo: Arhitektonski fakultet u Sarajevu; 2017.

4. Hadrović A. Water and man in autoshthonous symbiosis in Bosnia and Herzegovina. Sarajevo: Avicena; 2014. 